\title{
Vodenje in (neprofitni) menedžment v socialni pedagogiki
}

\author{
Andrej Berdajs \\ Univerza na Primorskem, Pedagoška fakulteta
}

\section{Uvod}

Organizacije, kjer se večinoma srečujemo s socialnopedagoško dejavnostjo, so predvsem vzgojni zavodi, vrtci, osnovne šole, srednje šole, stanovanjske skupine, centri za socialno delo, dijaški domovi, zapori, različne organizacije s področja dela $\mathrm{z}$ zasvojenimi, s težje zaposljivimi, $\mathrm{z}$ osebami s težavami v duševnem zdravju in različna društva ter nevladne organizacije. Socialni pedagog pri svojem delu vedno uporablja postopke in veščine vodenja. Ne samo takrat, ko je vodja kakšne od naštetih organizacij, pri svojem delu vedno vodi posameznike ali skupine skozi proces $\mathrm{k}$ zadanemu cilju. Kot osnovno mora obvladovati vodenje in organiziranje lastnega delovanja in razvoja. Predvsem mora biti vešč evalvacije lastnih postopkov, izmenjave izkušenj s kolegi in načrtovanja svojih korakov in uporabljanih metod pri svojem delu. Poznavanje in obvladovanje socialnih veščin mu je pri tem v veliko pomoč, ravno tako pa mora znati uporabljati osnovna pravila vodenja (menedžmenta).

V nadaljevanju bomo pregledali, kako je polje neprofitnih organizacij definirano $\mathrm{v}$ različnih državah in kakšne so njegove specifike $\mathrm{v}$ slovenskem prostoru. Poudarili bomo pomembne vsebine vodenja, kot so upravljanje s človeškimi viri, snovanje kulture neprofitnih organizacij in kaj je pomembno pri opredeljevanju organizacijske strukture. Opisali bomo posebnosti v snovanju vizije $\mathrm{v}$ neprofitnih organizacijah in izhodišča $\mathrm{v}$ pristopu 
do njihovega trženja. Opredelili bomo pomembnost ugotavljanja uspešnosti in usmeritve pri uvajanju sprememb v neprofitnih organizacijah.

\section{Posebnosti in vrste neprofitnih organizacij}

Temeljna opredelitev neprofitnih organizacij je, da služijo praviloma javnemu interesu ali interesu določenih skupin. Njihovo delovanje (in preživetje) je velikokrat odvisno od osnovnega pristopa države, ki se lahko bistveno razlikuje (Kolarič, 2001):

- $\quad$ lahko gre za liberalni tip sistema, kjer so v celoti prepuščene delovanju trga (ZDA, Avstralija);

- $\quad$ v konservativno-korporativističnem tipu sistema država primora večino državljanov, da se zavarujejo, sama pa nudi servis za tiste, ki tega ne zmorejo (Nemčija, Avstrija, Francija, Belgija);

- $\quad$ v socialdemokratskem tipu sistema država poskrbi za njegovo delovanje v celoti (skandinavske države);

- $\quad$ v katoliškem tipu je država v ozadju in pušča prostor, ki ga v večini pokrijejo cerkvene organizacije (Italija, Španija, Portugalska);

- $\quad$ v etatističnem tipu sistema država ne izpusti iz rok nadzora nad njim (postsocialistične države).

Vidimo, da se pristopi v različnih državah (tudi v okviru EU) zelo razlikujejo. Različna so tudi konkretna področja delovanja, ki jih pokrivajo neprofitne organizacije. Za Slovenijo velja, da je velika večina neprofitnih organizacij s področja kulture in rekreacije (športa) ter gasilska društva. Podoben odstotek je značilen tudi za druge srednjeevropske postsocialistične države. V ZDA, na Japonskem in Nizozemskem je večina neprofitnih organizacij s področja zdravstva. V Avstriji, Franciji, Nemčiji in Španiji prednjačijo socialne storitve. V Veliki Britaniji, Izraelu, Irski in Belgiji jih je največ na področju izobraževanja. Uravnoteženo zastopana področja najdemo na Finskem, v Avstraliji in Kolumbiji (Rončević, 2001).

Kot specifiko za Slovenijo lahko navedemo, da se še vedno pozna vpliv zaradi okoliščin, ko je v prejšnjem sistemu država (politika) obvladovala vse možne veje delovanja neprofitnih organizacij. Ob prehodu v nov sistem pa konstantno nastaja vrzel med realno prakso in nedodelano izvedbeno zakonodajo, iz katere izhaja veliko problemov, predvsem na področju angažiranja kadrov in odsotnosti spodbud davčnega sistema (Rončević, 2001).

$S$ finančnega stališča je glavna in osnovna razlika med profitnimi in neprofitnimi organizacijami ta, da je glavni cilj prvih ustvarjanje dobička 
glede na vložena sredstva, pri drugih pa je v ospredju izpolnjevanje njihovega poslanstva, medtem ko doseganje dobička ne igra glavne vloge.

S stališča dobrega vodenja (menedžmenta) vsako organizacijo vodimo $\mathrm{v}$ smeri, da bi v čim večji meri uresničili namene in cilje, zaradi katerih je bila ustanovljena. Ni pa tako bistvenih razlik, če je poudarek na materialnem dobičku, javnem ali zasebnem interesu ali na humanistično moralnih vrednotah (Jelovac, 2001).

Večina okvirov in smernic za delovanje neprofitnih organizacij je postavljena z določili Zakona o zavodih, Zakona o društvih idr. Osnovni cilji, ki so s pravnimi akti določeni ob ustanovitvi teh organizacij, so predvsem zadovoljevanje različnih družbenih potreb (finančni dobiček, kot smo že omenili, ne more biti glavno vodilo). Vse organizacije pa tako kot gospodarske družbe delujejo v okolju trga in so podvržene logiki bilance uspeha. Razumljivo in logično je, da se tudi v neprofitnih organizacijah tako imenovana prodaja storitev utemeljuje kot potrebna dejavnost, ki določa odnos do posameznih aktivnosti $v$ delovnem procesu. $V$ neprofitnih organizacijah je tako stalnica uskladitev pridobivanja sredstev (v okviru osnovne dejavnosti, z različnimi projekti ipd.) s poslanstvom osnovne dejavnosti. Problem se poglablja predvsem pri težavah s kadrovsko zasedbo in $s$ finančnimi sredstvi, ki jih je potrebno vložiti v projekte, ki morda ne bodo uspeli.

N. Hrovatin (2001) navaja, da neprofitne organizacije v izhodišču služijo širšemu družbenemu interesu. Po njenem so neprofitne organizacije lahko skupni pojem za vso javno upravo, za vse družbene dejavnosti in za prostovoljne organizacije, katerih poslovanje nima le cilja dobička. Če poslovanje organizacije pripelje do dobička, se le-ta praviloma vlaga v osnovno dejavnost organizacije.

To pomeni, da so neprofitne organizacije lahko vladne ali nevladne. Tako so pravne osnove za njihovo delovanje definirane ne le $\mathrm{v}$ zakonih o zavodih, ustanovah in društvih, ampak tudi v zakonih o gospodarskih družbah. Njihova področja, kjer se jih tradicionalno najde največ, so socialni sektor (brezdomstvo, okoljevarstvo, nasilje) in organiziranje družbenih dejavnosti (izobraževanje, šport, kultura, verske dejavnosti).

Osnova za njihovo operativno delovanje je poleg zakonskih aktov natančna definicija njihovega poslanstva. Definiranje poslanstva je izhodišče za določanje konkretnih nalog in aktivnosti. Tu nastane večji problem kot pri profitnih organizacijah, saj je praviloma potrebno zadovoljiti interese različnih uporabnikov (strank) in akterjev: otrok, staršev, "gojencev«, za- 
poslenih, stroke in države. $\mathrm{V}$ tem spektru je posebno pomembna vloga države, saj način in količina njene prisotnosti neposredno vpliva na obseg, $\mathrm{v}$ katerem se mora organizacija orientirati na svoj neposredni nastop na trgu (Hrovatin, 2001). Utemeljen je dvom, da bolj kot je organizacija usmerjena na trg in odvisna od njega, bolj se njena dejavnost oddaljuje od revnejših slojev družbe.

Kovač (2001) izhaja iz predpostavke, da ljudje zadovoljujejo svoje interese skozi trg, državo in civilno družbo. Razdelitev civilne družbe pa opravi na podlagi štirih vidikov:

- $\quad$ s formalnega vidika - dejavnosti delimo po poslanstvu na človekoljubne in tržne;

- $\quad$ z lastninskega vidika - dejavnosti civilne družbe so lahko vladne - javne službe ali privatne organizacije;

- $\quad$ z vidika vodenja - nekatere dejavnosti so profesionalno vodene, nekatere pa volontersko;

- $\quad$ z vidika končnih uporabnikov - nekatere dejavnosti so v javnem interesu, nekatere pa le v interesu ožjega članstva.

Avtor trdi, da neprofitni sektor (javna uprava, šolstvo, zdravstvo, kultura, šport in številne neformalne oblike civilne družbe) postaja čedalje pomembnejši segment družbe. Na vseh področjih ga opredeljuje tudi zelo velik preplet interesov. Kakor na eni strani razvoj globalizacije terja večji pomen civilnih institucij, tako na drugi strani kriza socialne države zahteva vedno bolj racionalne rešitve.

Osnovno poslanstvo socialne pedagogike - pomagati ljudem v stiski in področja delovanja socialnih pedagogov našo dejavnost v največji meri uvrščajo v sfero neprofitnih organizacij. V to domeno sodijo vse vzgojno-izobraževalne institucije (vrtci, osnovne šole, srednje šole, šole s prilagojenim programom, dijaški domovi), zavodi institucionalne vzgoje (vzgojni zavodi, zavodi socialnega skrbstva, varstveno delovni centri, zavodi za usposabljanje, zapori, prevzgojni domovi, mladinski domovi), zavodi socialnega varstva (domovi za starejše, krizni centri za žrtve nasilja, varstvo invalidov) ter v nevladnem sektorju področja humanitarnosti, preventivni programi, skupine za samopomoč in mladinsko delo. 


\section{Vodenje neprofitnih organizacij}

Teoretik znanosti vodenja in menedžmenta, Drucker (2001), izhaja iz dejstva, da se osnovni pristopi v menedžmentu profitnih ali neprofitnih organizacij ne razlikujejo.

Osnovni problem, ki v dobršni meri velja za vse neprofitne organizacije, je, da so kadrovsko podhranjene v segmentu strokovnih služb. Menedžer $\mathrm{v}$ neprofitni organizaciji mora večinoma sam opravljati dela pravnika, kadrovika, psihologa ipd. Za vsa ta področja nima na voljo posebnih strokovnih služb. Tako lahko zaključimo, da je vodenje neprofitnih organizacij s stališča vodje težje in predvsem bistveno bolj večplastno delo.

Zanimivo je tudi dejstvo, da pri vsakoletni izbiri menedžerja leta le-ta še nikoli ni bil izbran iz neprofitne organizacije. Prav tako nismo zasledili niti primera, da bi se uspešen menedžer iz gospodarstva preusmeril v neprofitni menedžment (za kar po vsej verjetnosti ni razlog le večja zahtevana heterogenost operativnega dela, ampak tudi drugačni razpoložljivi finančni okviri plače).

Težavnost vodenja neprofitnih organizacij morda povečuje tudi to, da ni jasne strateške vizije razvoje države, da se ne moremo izviti iz stalne krize izobraževalnega sistema in marginalnosti civilne družbe (Jelovac, 2001).

Pomen vodje za organizacijo je velik in se odraža na različnih področjih njenega dela in življenja. Njegovo delovanje se neposredno odraža na vtisu, ki ga organizacija daje navzven kot tudi navznoter do ostalih zaposlenih. Poleg koordiniranja dela, razdeljevanja nalog, nadzora nad izvedbo in ocenjevanja zaposlenih ima glavno vlogo pri snovanju vizije organizacije, načina njenega trženja ter skrbi in aktivno vpliva na kulturo in klimo, je snovalec in spodbujevalec sprememb.

\section{Upravljanje s človeškimi viri}

Upravljanje s človeškimi viri je proces, $\mathrm{v}$ katerem se $\mathrm{v}$ organizacijah na osnovi poslovne strategije načrtujejo potrebe po kadrih in $\mathrm{v}$ katerem se kadri zaposlujejo, razvijajo, vrednotijo, nagrajujejo in $\mathrm{z}$ njimi vzpostavljajo odnosi (Vodopivec, 2010). Pomembno je, da z znanjem, s spretnostmi zaposlenih upravljamo v skladu $\mathrm{z}$ njihovimi lastnostmi in cilji organizacije.

Upravljanje s človeškimi viri pomeni tudi, da zaposlenim pomagamo nadzirati in razvijati njihove lastne delovne kariere v sožitju s cilji organizacije (izobraževanje, usposabljanje, zastavljanje novih ciljev). Posebna 
skrb mora biti namenjena zaposlovanju novih delavcev in njihovemu uvajanju v delo.

Glede na to, da so neprofitne organizacije v večji meri storitvene, so človeški viri za njihovo dejavnost še bolj pomembni.

Vprašanja, na katera skušamo odgovoriti s pravilnim upravljanjem človeških virov v neprofitnih organizacijah, so po Svetliku (2001) naslednja:

- $\quad$ kako pridobiti zadosti ustrezno usposobljenih ljudi;

- $\quad$ kako iz njih izvabiti čim več ustvarjalne energije;

- $\quad$ kako doseči, da bodo svoje sposobnosti izpopolnjevali;

- $\quad$ kako jih v organizaciji obdržati - doseči, da jo bodo vzeli za svojo.

Vse to skušamo doseči $\mathrm{z}$ analizo delovnih procesov, s skrbjo za racionalno delitev dela, s stalnim spodbujanjem zaposlenih, $\mathrm{z}$ vlaganjem $\mathrm{v}$ njihovo izpopolnjevanje, s sprotnim ocenjevanjem njihovega dela in dosežkov.

Praviloma je $\mathrm{v}$ neprofitnih organizacijah denar kot motivacijsko sredstvo $\mathrm{v}$ večini primerov omejen, ob tem je največkrat število zaposlenih manjše od želja in potreb, in zato je nujno, da morajo zaposleni delati na več različnih področjih.

Ena osnovnih dilem je tudi ta, v kolikšni meri delovne potrebe pokrijemo $\mathrm{z}$ lastnimi kadri in katere dejavnosti ter v kolikšnem obsegu opravljamo z zunanjimi izvajalci.

Pri neprofitnih organizacijah, kjer so zaposleni socialni pedagogi, je s stališča upravljanja s človeškimi viri pomembna tista dimenzija, kjer skušamo doseči, da bodo le-ti svoje sposobnosti izpopolnjevali ter nadgrajevali svoje znanje in veščine s permanentnim dodatnim izobraževanjem ali funkcionalnim usposabljanjem. Možnost morajo imeti tudi za izmenjavo refleksij lastnega dela. Glede na to, da se večina socialnih pedagogov pri svojem delu s klienti stalno srečuje $\mathrm{z}$ lastnimi čustvenimi obremenitvami, jim je treba omogočiti supervizijo, kot njihovo stalno spremljajoče svetovanje. S tem preprečujemo stres in izgorevanja ob čustvenih in psihičnih obremenitvah.

\section{Kultura neprofitnih organizacij}

S kulturo organizacije označujemo definicijo socialne in fenomenološko unikatnost posamezne organizacijske skupnosti, ki vsebuje tako nematerialne kot materialne elemente (Beare, Caldwell in Millikan, 1992). Iz sociološkega vidika je kultura sistem dogovorjenih pomenov, spoznanj, simbo- 
lov in izkušenj, ki se izražajo v obnašanju in praksi članov organizacije, jih socialno definirajo ter jim dajejo občutek pripadnosti. Kultura organizacije pomeni način, kako le-ta deluje. Kultura ima osnovo v prepričanjih ljudi in njihovih vrednotah. Schein (1992) po Biloslavu (2007) kulturo organizacije določa na treh ravneh:

- na artefaktih ali pojavnih oblikah kulture (urejenost fizičnega okolja, uporabljan jezik in tehnologija, proizvodi, slog skupine (oblačenje, poimenovanja, izkazovanje čustev), legende o organizaciji, slovesnosti;

- na vrednotah (težnjah k privilegiranju nečesa pred drugim), velja, da so vrednote na meji med zavednim in nezavednim;

- $\quad$ na temeljnih podmenah (rešitve določenih situacij, ki jih organizacija privzame kot nesporne: vedenje, načini dojemanja ipd.).

Schein (1992) za posameznika pravi, da je njegovo vedenje odvisno od njegovih osebnih značilnosti in kulture organizacije, $\mathrm{v}$ kateri deluje. Posamezniki imajo generalno lahko operativno kulturo (izvajalci), inženirsko kulturo (načrtovalci procesov) in vodstveno kulturo (vodje).

Prav tako je kultura neke organizacije lahko močna (zanjo se zavzema večina članov) ali šibka (podpira jo le ožja skupina). Za uspešno delovanje organizacije in njeno rast je pogoj močna kultura (Biloslavo, 2007). Ob tem le-ta ni statična, temveč je v stalnem spreminjanju in dograjevanju.

Kultura organizacije, predvsem posamezne etape pri njenem ustvarjanju, je neposredno v rokah vodje. Le-ta se mora tega zavedati in jasno mu mora biti, h kašnemu cilju želi priti. Zaposleni vzpostavljajo niz splošno veljavnih mnenj o dogajanju v organizaciji in o vodji. Ta mnenja, ki se formirajo na podlagi v organizaciji veljavnih vrednot in stališč, niso nepomembna. Pogosto so razlog obnašanja in reakcij v odnosu zaposleni - vodja in zaposleni - uporabniki. Zato je prav, da vodja tega ne pušča vnemar in da se aktivno vključi v konstrukcijo vrednot in stališč določene (na primer, šolske) sredine.

Vsaka organizacija ima svojo lastno kulturo, ki je določena $\mathrm{z}$ individualnimi vrednotami, stališči in izkušnjami, ki jih prispevajo zaposleni. To nastane $\mathrm{z}$ načini, s katerimi zaposleni komunicirajo med seboj, in s sledmi, ki jih za seboj puščajo ti medosebni odnosi.

Robbins in Judge (2012) opredeljujeta organizacijsko kulturo kot skupno percepcijo, ki jo imajo člani organizacije. Pomeni sistem enakih pomenov, ki ločijo organizacijo od drugih organizacij. Gre za izbiro ključnih 
karakteristik, ki jih ima organizacija za vredne. Avtorja izpostavljata 10 karakteristik, ki se tičejo bistva kulture organizacij, in sicer:

- individualna iniciativa (stopnja odgovornosti, svobode in neodvisnosti posameznikov);

- $\quad$ toleranca tveganja (stopnja, do katere naj bi bili zaposleni agresivni, inovativni in naj bi tvegali);

- $\quad$ usmeritev (stopnja, do katere ustvarja organizacija jasne cilje in pričakovanja glede dela);

- integracija (do kakšne stopnje naj se enote $\mathrm{v}$ organizaciji integrirajo);

- podpora vodij (koliko vodje jasno komunicirajo, pomagajo in podpirajo podrejene);

- $\quad$ kontrola (število pravil in pravilnikov, stopnja direktnega nadzora nad zaposlenimi);

- identiteta (koliko se zaposleni identificirajo s celotno organizacijo - bolj kot recimo s svojim oddelkom ali s svojim poklicem);

- $\quad$ sistem nagrajevanja (koliko je ta sistem vezan na dosežke zaposlenih - namesto na delovno dobo, favoriziranje posameznikov in podobno);

- toleranca do konfliktov (koliko lahko zaposleni odkrito izražajo kritike in so konfliktni do vodij);

- $\quad$ komunikacijski vzorci (stopnja, do katere so komunikacijski vzorci omejeni na formalno hierarhijo in avtoriteto).

Vsaka od teh karakteristik je nekje na kontinuumu od nizke do visoke. Na podlagi teh karakteristik lahko ocenimo stanje in oblikujemo skupno sliko kulture organizacije. Seveda nam ta slika pove, kako zaposleni zaznavajo deset karakteristik, ne pa, ali so jim le-te všeč ali ne. Kultura organizacije je opisni pojem in po tem se loči od zadovoljstva s službo. Organizacijska kultura se ukvarja s percepcijo posameznih karakteristik, zadovoljstvo s službo pa s čustvenimi odzivi na delovno okolje (kultura organizacije je opisni pojem, zadovoljstvo s službo pa vrednostni).

$\mathrm{V}$ organizaciji pogosto ne obstaja enotna kultura. Obstaja dominantna kultura, ki izraža glavne vrednote, ki jih sprejema večina zaposlenih. Obstajajo pa tudi subkulture, ki se razvijejo po posameznih oddelkih. Do tega pride predvsem takrat, ko obstajajo lokacijsko oddaljene enote.

Robbins in Judge (2012) trdita, da je kultura lahko šibka ali močna. Močna je tedaj, če so glavne vrednote intenzivne in široko razširjene. 
Močna kultura povečuje povezanost vedenja. Je lahko nadomestek za formalizirana pravila in zato povzroča (brez napisanih pravil) predvidljivost v organizaciji, red in skladnost ter zmanjšuje fluktuacijo. Omejuje organizacijo od drugih organizacij, predstavlja identiteto članov, olajšuje upoštevanje širšega organizacijskega interesa, predstavlja sistem socialne stabilnosti (vedenje, nenapisana pravila) in stališča članov. Že ob vstopu v službo ima kultura velik vpliv na selekcijo kandidatov. Nekdo postane polnopravni član organizacije šele, ko sprejme kulturo organizacije. Za kulturo ne moremo reči, da je dobra ali slaba, ima pa veliko funkcij, ki so pomembne tako za organizacijo kot za posameznike. Lahko pa se tudi zaradi funkcije konsistentnosti in določanja vedenja posameznikov spremeni v »coklo« razvoja organizacije.

Beare idr. (1992) opozarjajo, da je kultura včasih v nesoglasju z deklariranimi cilji organizacije. Za močno in usklajeno kulturo je potrebna tesna povezava med nematerialnimi in konceptualnimi elementi ter materialnimi, zunanjimi izrazi in simboli.

Trenutne navade in tradicije $\mathrm{v}$ organizaciji so $\mathrm{v}$ glavnem posledica tega, kar se je že prej delalo in se je izkazalo za uspešno. Utemeljitelji kulture v organizaciji imajo največji vpliv na zgodnjo kulturo. Utemeljitelji imajo vizijo o tem, kaj naj bi organizacija bila. Ne omejujejo jih prejšnje navade ali ideologije. Kultura organizacije je rezultat interakcije med zamislimi in predpostavkami utemeljiteljev in tem, kar se zaposleni naučijo direktno iz lastnih izkušenj. Kulturo potem ohranja pri življenju proces selekcije kadrov, vodenje in socializacija delavcev znotraj organizacije (Robbins in Judge, 2012).

Socialni pedagog v naravi svojega delovanja - ko je njegova aktivnost usmerjena na osebo, ki je potrebna pomoči - ustvarja tudi kulturo svoje organizacije (institucije, zavoda), ki ji pripada. Z dobrimi odnosi, primernimi storilnostnimi pritiski in dosežki lahko gradi socialno kulturo, ki bo usmerjena $\mathrm{k}$ ljudem, njihovemu počutju in ne le rezultatom. Predvsem za reševanje problemov posameznikov, vključenih v organizacijo, je taka kultura najprimernejša.

\section{Organizacijska struktura}

Organizacijska struktura opredeljuje formalno ureditev organizacije glede razdelitev nalog, izvajalce nalog, njihove medsebojne odnose, pretok informacij ter linije avtoritete in vodenja (Vodopivec, 2010). 
Isti avtor loči formalno strukturo in neformalno, ki dopolnjuje funkcioniranje organizacije. Strukturo organizacije sestavljajo: tehnična struktura (razdelitev in združevanje delovnih nalog), komunikacijska struktura (smeri komunikacije, poročanje), motivacijska struktura (formalna in neformalna) in struktura vodenja (stopnje hierarhije, zadolžitve, pozicije posameznikov).

$\mathrm{Z}$ bolj dinamično dejavnostjo organizacije, njeno pojavo na trgu ali $\mathrm{z}$ razvojem se pojavi tudi potreba po drugačni in specifični organizacijski strukturi. Vodja mora pravočasno reagirati, predlagati in uvesti tako strukturo organizacije, da je prilagojena njenemu delu in življenju, da bo sam kot vrh te strukture svoje delo dobro opravljal.

Vodja mora znati vse večje in manjše skupine povezati v celoto, ki tvori organizacijo. Način tega povezovanja nam določi odnose - tako imenovano strukturo organizacije. Vodjo naj bi pri sprejemanju strukturnih odločitev vodili temeljni organizacijski koncepti, ki v glavnem veljajo za vse vrste organizacij. Ti temeljni organizacijski koncepti nam določajo vodenje organizacije. Pri snovanju strukture organizacije je potrebno upoštevati zakonske zahteve (predvsem v delu, ki določa soodločanje zaposlenih) in cilje organizacije.

Organizacijske strukture imajo otipljiv izraz v obnašanju in aktivnosti članov določene organizacije. Te strukture nam zelo nazorno prikazujejo poti odločanja, komunikacije, relacij moči in avtoritete, ki jih favorizira vodja kot »kreator« te strukture.

Lipičnik (1999) opozarja, da notranja organizacija in način njenega delovanja predstavljata glavna pogoja uspešnosti organizacije. Zato je pomembno, da ji posvetimo dovolj pozornosti. Vedno naj bi ju oblikovali cilji, naloge, nosilci nalog in njihova medsebojna razmerja. Cilji določajo naloge, ki jih morajo nosilci nalog izvršiti za doseganje cilja. Medsebojna razmerja med posameznimi sklopi ne smejo biti toga, ampak dovolj fleksibilna, da omogočajo hitro, učinkovito in stalno komunikacijo.

V organizacijski strukturi neprofitnih organizacij, kjer je zaposlenih več socialnih pedagogov, to daje možnost formiranja tima, ki poleg osnovnega sodelovanja in izmenjave izkušenj nudi tudi možnost skupnih refleksij in evalvacij njihovega dela. Če pa imamo v isti organizaciji zaposlene tudi druge strokovnjake iz različnih poklicev pomoči (socialni pedagogi, pedagogi, psihologi, socialni delavci), to omogoča osvetlitev problemov iz različnih zornih kotov. Sinergija in večplastni pogled na reševanje nekega proble- 
ma, ki lahko nastane ob taki organizacijski strukturi, sta izrazito pozitivna pri iskanju rešitev.

\section{Snovanje vizije organizacije}

Vizija delovanja neprofitne organizacije že na prvi pogled organizacijo loči od tiste, ki je profitno naravnana.

Načrtovanje razvoja organizacije je sestavljeno iz snovanja njene vizije in načrtovanja poti, ki nas pelje k uresničevanju le-te. Osnova za snovanje ali spreminjanje vizije organizacije mora biti fleksibilno odzivanje na spremembe v okolju, stroki, trgu in sistemu dela. Vizija je predstava o zaželeni prihodnosti. $\mathrm{V}$ osnovi mora zasnovati vizijo delovanja in razvoja organizacije njen vodja. Pomembno je, da vizijo konstruira na podlagi tako zunanjih dejavnikov kot tudi konkretne ekipe zaposlenih, ki bodo vizijo skupaj z njim udejanjili. Zato je potrebno, da posamezne segmente te vizije preigra in pretrese skupaj s posamezniki in skupinami, preden vizija dobi končno in potrjeno obliko. Nujno je, da se mora za uspešno delovanje organizacije v tej viziji videti vsak posameznik in vsaka skupina v organizaciji - ne sme biti to le vizija vodje. Resman (1994) poudarja, da ko snujemo vizijo razvoja organizacije moramo k delu pritegniti ne le zaposlene, temveč tudi ljudi iz okolja, v katerem organizacija deluje, in potencialne uporabnike, da ne bo vizija preveč abstraktna.

V. Vodopivec (2010) vizijo organizacije opredeljuje kot točko v prihodnosti življenja in delovanja organizacije. Njen namen je motivacijski naboj za zaposlene. Predstavlja kreativno pretvorbo poznavanja bodočih sprememb v okolju in sposobnosti organizacije za doseganje postavljenih smeri razvoja. Je slika možnega in želenega položaja organizacije v prihodnje. Bistveno je, da je konstruirana na osnovi realnih možnosti, da je taka, da jo razumejo in v njo verjamejo vsi zaposleni. Njen namen je: kontrola nad razvojem organizacije, oblikovanje strategije delovanja organizacije in spremembe kulture organizacije.

Skladno z vizijo organizacije morajo biti jasni tudi kratkoročni cilji. Medtem ko je vizija včasih bolj abstraktna, morajo biti kratkoročni cilji bolj pragmatični, usmerjeni v operativno akcijo. Konkretizacija vizije določa poslanstvo organizacije in nam pomaga pri definiranju (Vodopivec, 2010):

področij delovanja organizacije,

- koristnikov uslug organizacije,

- načina delovanja organizacije, 
- osnovnih vrednot in vzorcev obnašanja $\mathrm{V}$ organizaciji in $\mathrm{Z}$ okoljem.

Vizija kot tudi kratkoročni cilji niso nespremenljivi. Ene in druge je potrebno večkrat premisliti in ponovno preverjati. Vedno se je potrebno spraševati, ali še delamo to, kar smo želeli.

Vizija organizacije s socialnopedagoškim delovanjem je tako določena $z$ organizacijo nudenja pomoči neki ciljni skupini, ki to pomoč potrebuje, na optimalen način $z$ upoštevanjem etičnih načel in socialno sprejemljivih vzorcev vedenja v organizacijah in družbi.

\section{Trženje (marketing) v neprofitnih organizacijah}

Današnji koncept prostega trga opredeljujejo globalizacija in neoliberalni pristopi. Trg se od nadzorovanih postopkov vedno bolj premika $\mathrm{k}$ avtonomnosti. Situacijo na trgu najbolj opišejo pojmi, kot so: iniciativa posameznika, svobodna izbira, tekmovalnost, suverenost porabnika. Če želimo s trgom urejati področja, ki so glavna blaginja skupnosti in posameznika (šolstvo, zdravstvo in socialna varnost), to pomeni zaton socialne države (Trnavčevič, 2007).

$Z$ večanjem pomena trga se država umika tudi s področja nadzora nad organizacijami. Del nadzora naj bi se realiziral z različnimi koncepti ugotavljanja kakovosti, z eksternostjo rezultatov in poudarjenim vplivom menedžerjev. V praktičnem primeru imamo obliko trga, ki je definiran z možnimi izbirami odjemalcev in tekmo med polavtonomnimi izvajalci. Apeli nasprotnikov tržnih odnosov v smeri, »naj država uredi red na trgu in zagotovi socialne pravice ter enake možnosti«, se zavračajo $\mathrm{z}$ argumentiranjem, da moramo vzpostaviti primerljivost z drugimi državami EU (Trnavčevič, 2007).

Ko se organizacija pojavi na trgu, skuša koncipirati postopke in načine, kako bo s svojo dejavnostjo čim bolj odzivna na potrebe potencialnih odjemalcev. Trg seveda spodbuja tekmovanje med organizacijami $\mathrm{z}$ istega področja, kar lahko vpliva na rast kvalitete posamezne organizacije in bolj smotrno uporabo razpoložljivih sredstev. Država spodbuja vzpostavitev trga s spremembo zakonodaje in s spremenjenim financiranjem, ki omogoča večjo avtonomnost organizacij ter $\mathrm{z}$ spodbujanjem nastajanja zasebnih neprofitnih organizacij.

Marketing v neprofitnih organizacijah seveda vodi v večjo povezanost teh organizacij s profitnimi. Da so organizacije v takih partnerstvih uspeš- 
ne, morajo spreminjati svojo kulturo, prevzemati morajo pravila marketinških odnosov. Neprofitne organizacije za dosego svojih ciljev uporabljajo metode iz marketinških aktivnosti profitnih podjetij, ki so lahko tudi neučinkovite, če hkrati v organizacijah niso sprejeli tudi nove marketinške kulture. To seveda vodi v komercializacijo neprofitnega sektorja.

Tržno naravnana organizacija je po svoji kulturi poudarjeno pragmatična. Njene prednostne naloge delovanja določa zadovoljevanje potreb potencialnih odjemalcev (Snoj, 2007).

A. Trnavčevič (2007) opredeljuje, da trženje ali marketing organizacije pomeni naslednje: uzaveščenje, kaj je organizacija sposobna narediti; ugotovitev, kaj tvoji potencialni uporabniki želijo, potrebujejo ali so pripravljeni kupiti; doseči v zavesti potencialnega uporabnika, da je organizacija tisto, kar on želi, sposobna narediti; ter realizacija te produkcije $\mathrm{z}$ istočasnim informiranjem o aktivnosti organizacije. Vedno pa se moramo zavedati, kaj, zakaj in komu tržimo.

Logaj (2007) meni, da ima marketing neprofitne organizacije naslednje specifike: zagotoviti mora vnaprej določene socialne zahteve in operirati mora $\mathrm{v}$ tržnem okolju, ki je pogosto omejeno s poudarjenimi cilji organizacije.

Marketinške dejavnosti se začno $\mathrm{z}$ ugotovitvijo potreb in želja potencialnih uporabnikov in $\mathrm{z}$ definicijo trenutnega stanja delovanja organizacije. Iz teh izhodišč predlagamo in načrtujemo potrebne nove dejavnosti. Pomembna vloga vodje je, da spodbuja zaposlene in pripomore k spremembi organizacijske kulture tako, da postane marketinška naravnanost interes vseh.

V trženju socialnopedagoških uslug izhajamo iz vnaprej določenih socialnih zahtev, ki jih družba ali organizacija pričakuje od prejemnikov teh uslug, ter njihovih primanjkljajev, ki jim to onemogočajo ali otežujejo.

\section{Ugotavljanje uspešnosti neprofitnih organizacij}

V nobeni organizaciji, profitni ali neprofitni, ne moremo meriti uspešnosti le s finančnim dobičkom na podlagi številk iz bilance uspeha. Uspešnost organizacije določajo tudi različna kvalitativna merila (Jelovac, 2001).

Dejstvo je, da se merila in izhodišča ugotavljanja uspešnosti za profitne organizacije (gospodarske družbe) in neprofitne organizacije prepletajo. Instrumenti in načini merjenja uspešnosti neprofitnih organizacij morajo praviloma izhajati iz v osnovi definiranega poslanstva organizacije. 
Večinoma gre za kvalitativne elemente, ki so taksativno težje ugotovljivi (na primer zadovoljstvo). Prav je tudi, da jih kombiniramo s kvantitativnimi elementi (uspeh, število obravnavanih primerov) in splošen rezultat ugotavljamo na osnovi evalvacije.

M. Tekavčič (2002) navaja, da so ugotovitve o uspešnosti delovanja organizacije osnova, na kateri lahko $v$ organizaciji uvajamo spremembe $\mathrm{v}$ strategiji in konkretnih odločitvah $\mathrm{v}$ zvezi z delovanjem organizacije. Uspešnost organizacije moramo kvantitativno meriti in tudi kvalitativno presojati. Pri tem moramo opraviti naslednje korake: ločitev bistvenih aktivnosti od nebistvenih, analiziranje pomembnih bistvenih aktivnosti, primerjava opravljenih aktivnosti z najboljšimi znanimi primeri dobre prakse in preučevanje povezav med aktivnostmi.

Tudi pri socialnopedagoški dejavnosti lahko uspešnost delovanja opredeljujemo s kvantitativnimi kazalci, ki nam dajejo podatke o številu (uspešno ali neuspešno) obravnavanih primerov (oseb). Merilo za vsebinsko ugotavljanje uspešnosti socialnopedagoškega delovanja pa so kvalitativni kazalci, s katerimi ugotavljamo uspešnost in zadovoljstvo prejemnikov uslug oziroma primerjavo našega delovanja s primeri dobre prakse.

\section{Uvajanje sprememb v organizacije}

Splošna situacija v družbi, navade, življenjski stili, globalizacija, tehnološki in informacijski napredek pogojujejo stalno zahtevo po spremembah v vseh družbenih segmentih. A. Sinjur (2009, str. 362) pravi, »da morajo biti učitelji pri svojem delu ustvarjalni in fleksibilni, da lahko konstruktivno rešujejo težave, ki se pojavljajo znotraj pedagoškega procesa, in tako dosegajo vzgojno-izobraževalne cilje«.

Enako je pri vsaki drugi organizaciji - ne glede na panogo njene dejavnosti. Vsaka organizacija, ki želi izboljšati svojo uspešnost, mora spodbujati stalno učenje vseh svojih članov in jim s tem omogočiti napredek ter primeren odziv na potrebne spremembe (Erčulj, 1998).

Pri uvajanju sprememb moramo upoštevati trenutno stanje organizacije, njeno kulturo in klimo, značilnosti in zmožnosti zaposlenih.

Za uvajanje sprememb bi lahko uporabljali izraz organizirano izboljševanje dejavnosti. Seveda pa moramo v naprej definirati, kaj za neko sredino, organizacijo pomeni uspešnost (Drucker, 2001).

Vsaka sprememba v večji ali manjši meri ruši ravnotežje nekega stanja in s tem predvidljivost in varnost delovne situacije. S strani zaposlenih 
je velikokrat zaradi tega odziv odpor in strah. Zato je nujno, da vodja zaposlene pripravi na uvajanje sprememb, tako da novi okviri pomenijo izziv, ne pa le probleme in ovire.

Cilji vpeljevanja sprememb v življenje in delo organizacije so izboljšanje kakovosti delovanja posameznikov kot organizacije (Rupnik Vec in Rupar, po Schollaert, 2013). Važna je seveda smiselnost predvidenih sprememb. Bolje je, da vpeljujemo le tiste, ki pomembno in trajno prispevajo k izboljšanju uspešnosti organizacije. Spremembe niso uspešne, če zaposleni, ki naj bi spremembe vpeljevali, nimajo vpliva na njihovo načrtovanje (Schollaert, 2006).

Cilji sprememb morajo biti vedno usklajeni $\mathrm{z}$ vizijo organizacije in vedno morajo biti merljivi (Tavčar, 2002). Vodja mora vse zaposlene angažirati že tedaj, ko se definirajo cilji organizacije, da jih sprejmejo kot svoje. Uvajanje sprememb in razvojna aktivnost brez vizije je praviloma trošenje energije in časa brez pravega smisla.

Za kreiranje vizije je v osnovi zadolžen vodja. Pomembno pa je, da jo konstruira tako na podlagi zunanjih dejavnikov kot tudi konkretnih značilnosti in sposobnosti zaposlenih, $\mathrm{s}$ katerimi bo to vizijo skupaj v prihodnosti realiziral. Vizija pa ne sme biti le vizija vodje. V njej se mora videti vsak posamezni zaposleni. Ugodno je, da vsi zaposleni na pobudo vodje neposredno sodelujejo pri opredeljevanju posameznih segmentov vizije.

Skladno z vizijo organizacije morajo biti definirani tudi kratkoročni cilji delovanja. Medtem ko je vizija lahko malo bolj abstraktna, morajo biti kratkoročni cilji povsem pragmatični, osnova za konkretno akcijo. Vedno pa moramo imeti v zavesti, da tako vizija kot kratkoročni cilji niso nespremenljivi. Ene in druge je potrebno večkrat preveriti in premisliti njihovo utemeljenost.

Demokratičen pristop k uvajanju sprememb da bistveno več možnosti, da vsi zaposleni sprejmejo in aktivno delajo v postopkih njihovega uvajanja.

Koren (2006, po Nader, 1998) loči med stalnimi spremembami s ciljem odprave problemov delovanja organizacije in izboljšanja uspešnosti ter radikalnimi spremembami, ki so vezane na strategijo delovanja organizacije in njenih struktur.

Schollaert (2006, po Van Dougen, De Laat in Maas, 1996) loči tri vrste sprememb, in sicer:

radikalne spremembe (gre za izboljšavo v tehničnem smislu delovanja organizacije); 
- adaptivne spremembe (tu vpeljujemo novosti, ki ne zahtevajo sprememb v mišljenju);

- razvojne spremembe (ne gre le za spremenjeno ravnanje, ampak za nova stališča, pojmovanja, prepričanja, za razvoj novih kompetenc).

Drucker (2001, po Dimovski, 2005) glede uvajanja sprememb predpostavlja naslednja izhodišča: vsako spremembo je treba uvajati postopno, pred uvedbo spremembe pretehtajte stroške in zagotovite potrebna sredstva, spremembe ne smejo nasprotovati identiteti organizacije in stalno nagrajujte tiste, ki največ prispevajo $\mathrm{v}$ procesu uvajanja sprememb.

$\mathrm{V}$ današnjih časih uvajanje sprememb $\mathrm{v}$ organizacijo ni projekt $\mathrm{z}$ opredeljenim končnim rokom. Stalne spremembe dejavnikov okolja zahtevajo tudi stalnost sprememb v organizacijah, če te želijo ohranjati svoj položaj v prostoru (ali ga celo izboljševati).

Zelo pomemben del uvajanja sprememb je evalvacija (Štrajn, 200o). Z vrednostnim, količinskim in kakovostnim tehtanjem rezultatov neke nove dejavnosti, ki smo jo vpeljali v delo šole, dobimo učinkovite informacije o smotrnosti uvedbe sprememb. Postopek evalvacije in načrtovanja naslednjih korakov, ki sledijo iz nje, je proces, kjer se lahko omogoči veliko sodelovanja med zaposlenimi. Evalvacija po Schollaertu (2006) je smiselna med posameznimi akcijskimi koraki vpeljevanja sprememb in naj bi skušala odgovoriti na naslednja vprašanja:

- $\quad$ Ali smo še vedno na pravi poti?

- $\quad$ Ali se približujemo cilju?

- $\quad$ Ali naš cilj še vedno ostaja tak, kot smo si ga zamislili?

- Kaj je treba storiti, da pridemo na pravo pot?

- Kaj smo do sedaj že dosegli?

- Kaj je dokaz tega?

- Kaj smo se naučili iz vsega tega?

Sprememba, ki ne povzroči odpora, sploh ni sprememba, ampak nadaljevanje stanja, ki trenutno ustreza večini (Tavčar, 2002).

Razlogi za odpor so (Tavčar, 2009, po Robbins, 1991) ogrožene koristi (odvzemanje ali razvrednotenje dosedanjih koristi), sprememba utečenih navad, ogrožena varnost (nova tveganja), strah pred neznanim, sprejemanje le tistih dejstev o spremembah, ki se ujemajo z njihovimi navadami. 
Odpore zaposlenih do uvajanja sprememb lahko zmanjšamo ali čisto odpravimo z naslednjimi aktivnostmi (Koren, 2006, po George in Jones, 1999):

- $\quad$ z intenzivno in kvalitetno komunikacijo z zaposlenimi (odpori se velikokrat porajajo zaradi pomanjkanja informacij);

- $\quad$ z izobraževanjem in usposabljanjem na področjih, kjer uvajamo spremembe (odpori so velikokrat posledica nevednosti);

- $\quad$ s sodelovanjem čim večjega kroga zaposlenih in pooblaščanjem posameznikov za posamezne aktivnosti (distribucija moči);

- $\quad$ s podporo zaposlenim (svetovanje, izobraževanje);

- $\quad$ s pogajanji in dogovarjanjem (vodja tako dobi odziv zaposlenih na svoje ideje);

- $\quad \mathrm{z}$ manipulacijo (selektivno informiranje kot preprečevanje oviranja procesa sprememb);

- $\quad s$ prisilo (s tem pospešimo uvedbo sprememb, a velikokrat ob nezadovoljstvu zaposlenih, ki sprememb ne vzamejo za svoje).

Slabosti in nevarnosti, ki jih zaposleni vidijo v uvajanju sprememb, lahko s primerjalno analizo spremenimo v prednosti in izzive (Škrinjarič, 2006). Zavedati se pa moramo, da so za uspešno vpeljavo sprememb v kolektiv potrebni tudi kompromisi med vsemi, ki so vanje vpleteni. A. Sinjur (2009, str. 365) pravi, »da mora učitelj v pogojih globalne družbe, poleg pedagogike, menedžmenta in vodenja $\mathrm{v}$ izobraževanju, obvladati še vrsto drugih sposobnosti in spretnosti«.

Zelo važna je stalna in intenzivna komunikacija med vsemi člani kolektiva s ciljem prenosa informacij in znanja (diskusije, predavanja) ter iskanjem najustreznejših rešitev za probleme. Na začetku procesa je potrebno definirati pričakovanja, želje, se soočiti z morebitnimi strahovi in pomisleki. Odločilno vlogo v postopku uvajanja sprememb v kolektivu ima lahko tako imenovani razvojni tim, ki reflektira nameravane spremembe in procese njihovih vpeljevanj, zagotavlja izmenjavo informacij med zaposlenimi (Rupnik Vec in Rupar, 2013). Med člani takega tima je dobro, da so tisti, ki so odprti za spremembe, ki se radi učijo in ki znajo spodbujati tudi druge. Tak tim lahko bistveno vpliva na ustvarjanje pozitivne klime za spremembe (Rupnik Vec in Rupar, 2013). Tim reflektira nameravane spremembe, zbira, pripravlja in razvija podporna gradiva, zagotavlja in spodbuja izmenjavo mnenj med člani kolektiva. Osnovno delo takega tima 
je utemeljitev smiselnosti sprememb (Rutar Ilc, 2008). Nujno je, da kolektiv zaupa v vodstvo in morebitni tim za uvajanje sprememb.

Vodja se mora angažirati, da ustvarja primerno okolje, ki je naklonjeno uvajanju sprememb. Zaposleni so načeloma zelo zainteresirani, da vplivajo na delovanje organizacije $v$ prihodnje, saj bodo sami del tega delovanja. To, da gredo vsi člani kolektiva skupaj skozi proces kreiranja vizije organizacije, daje vsem odgovornost in jim dviguje moč za lastno delovanje. Njihove strahove in nemir pred novitetami mora vodja $\mathrm{z}$ razumevanjem sprejeti. Vseskozi je zaposlene potrebno osveščati, da bo večina rezultatov sprememb vidna šele po določenem času (predvsem, če s spremembami posegamo v kulturo organizacije).

Vpeljevanje sprememb $\mathrm{v}$ organizacijo s socialnopedagoško dejavnostjo lahko pogojujemo s spremembami, ki so ji podvržene ciljne skupine našega delovanja (na to v veliki meri vpliva splošno stanje v družbi). Najbolj koreniti in vsebinski premiki naše dejavnosti pa so odvisni od razvoja stroke in vpeljevanja novih organizacijskih pristopov in praks $\mathrm{v}$ socialnopedagoško delovanje.

\section{Sklep}

Ugotavljamo, da se socialnopedagoška dejavnost v največji meri realizira na polju neprofitnih organizacij. Ob tem velja, da vodenje neprofitnih organizacij danes doživlja intenzivne spremembe predvsem na segmentu marketizacije vseh področij. Tržna naravnanost dejavnosti neprofitnih organizacij bistveno vpliva na njihovo delovanje. Zato lahko zaključimo, da je s stališča vodenja teh organizacij prvi pomembnejši segment upravljanje s človeškimi viri, kjer je cilj, da vodja zna izbrati prave osebe za konkretna delovna mesta ter da stalno skrbi za njihovo motiviranost in možnosti profesionalnega razvoja. Prav tako je potrebno, da se $\mathrm{v}$ teh organizacijah vzpostavi socialna kultura, ki bo posameznikom (tako tistim, ki nudijo pomoč, kot tistim, ki jo sprejemajo) prijazna. V organizacijski strukturi moramo omogočiti formiranje strokovnega tima, ki bo osnova za izmenjavo izkušenj in skupne evalvacije dela. Tudi v snovanju vizije in poslanstva neprofitnih organizacij s socialnopedagoško dejavnostjo moramo biti usmerjeni v optimalno nudenje pomoči različnim ciljnim skupinam. Ne smemo dopustiti, da zaradi zahtev trga zanemarjamo potrebe uporabnikov, zaradi katerih je bila neprofitna organizacija ustanovljena. Glede na generalno poslanstvo neprofitnih organizacij, ki je v večini primerov usmerjeno k zadovoljevanju javnih družbenih potreb, je velikokrat težko obravnavati produkte njiho- 
vega delovanja kot izdelke ali usluge, ki so podvrženi tržnim zakonitostim. Če pogledamo polje socialnopedagoške dejavnosti, ki je usmerjena k delu s socialno šibkejšo, problematično in velikokrat marginalizirano populacijo, pretirano uvajanje tržnih zakonitosti lahko privede do zmanjševanja ali celo zapiranja socialnopedagoških uslug delu populacije, ki te usluge najbolj potrebuje. Ugotovimo lahko tudi, da je pomembno poznavanje kvantitativnih in predvsem kvalitativnih kazalcev našega dela, na podlagi katerih lahko ocenimo uspešnost delovanja. Zaključimo lahko, da s pravočasnim in aktualnim uvajanjem sprememb na podlagi novih družbenih zahtev ali novih doktrin stroke zagotavljamo, da naše socialnopedagoško delovanje ostane aktualno in da $\mathrm{z}$ njim dosegamo zastavljene cilje.

\section{Literatura}

Beare, H., Caldwell, B., in Millikan, R. (1992). Creating an excellent school. Some new management techniques. London: Routledge.

Biloslavo, R. (2007). Kultura organizacije. V A. Trnavčevič (ur.), Ko država šepeta (str. 29-56). Koper: Fakulteta za management.

Dimovski, V. (2005). Učeča se organizacija. Ljubljana: GV založba.

Drucker, P. (2001). Managerski izzivi v 21. stoletju. Ljubljana: GV založba.

Erčulj, J. (1998), Učeča se organizacija - izziv za učiteljev strokovni razvoj. Ljubljana: Vzgoja in izobraževanje, 29(3), 21-25.

Hrovatin, N. (2001). Ekonomski vidiki menedžmenta nevladnih organizacij. V D. Jelovac (ur.), Jadranje po nemirnih vodah managementa nevladnih organizacij (str. 36-46). Ljubljana: Zavod Radio Študent.

Jelovac, D. (2001). Odisejada krmarjev neprofitnega sektorja. V D. Jelovac (ur.), Jadranje po nemirnih vodah managementa nevladnih organizacij (str. 2-10). Ljubljana: Zavod Radio Študent.

Kolarič, Z. (2001). Različni znanstveno-teoretski pristopi k preučevanju neprofitnih organizacij. V D. Jelovac (ur.), Jadranje po nemirnih vodah managementa nevladnih organizacij (str. 11-22). Ljubljana: Zavod Radio Študent.

Koren, M. (2006). Ključni dejavniki uspešnosti uvajanja sprememb v podjetje v slovenskih razmerah (Magistrsko delo). Univerza v Ljubljani, Ekonomska fakulteta, Ljubljani.

Kovač, B. (2001). Lobiranje v neprofitnem sektorju. V D. Jelovac (ur.), Jadranje po nemirnih vodah managementa nevladnih organizacij (str. 108-115). Ljubljana: Zavod Radio Študent.

Lipičnik, B. (1999). Organizacija podjetja. Ljubljana: Ekonomska fakulteta. 
Resman, M. (1994). Ravnatelj in vizija šole. Sodobna pedagogika, 45(3-4), 122-132.

Robbins, P. S., in Judge, T. A. (2012). Organizational behaviour. Englewood Cliffs, NJ: Prentice Hall.

Rončević, B. (2001). Različni znanstveno-teoretski pristopi k preučevanju neprofitnih organizacij. V D. Jelovac (ur.), Nekaj nastavkov za sociološko obravnavo nevladnih organizacij (str. 23-35). Ljubljana: Zavod Radio Študent.

Rupnik Vec, T., in Rupar, B. (2013). Vpeljevanje sprememb v šole. Ljubljana: Zavod Republike Slovenije za šolstvo.

Schollaert, R. (2006). Pomen sprememb v izobraževanju. Vpeljevanje sprememb v šole: konceptualni vidiki. Ljubljana: Zavod Republike Slovenije za šolstvo.

Sinjur, A. (2009). Menedžment učiteljeve administracije. V M. Blažič (ur.), Menedžment v pogojih globalne recesije (zbornik prispevkov) (str. 361-366). Novo Mesto: Visoka šola za upravljanje in poslovanje.

Snoj, B. (2007). Marketinška kultura. V A. Trnavčevič (ur.), Ko država šepeta (str. 57-80). Koper: Fakulteta za management.

Svetlik, I. (2001). Menedžment človeških virov v neprofitnem sektorju. V D. Jelovac (ur.), Nekaj nastavkov za sociološko obravnavo nevladnih organizacij (str. 47-52). Ljubljana: Zavod Radio Študent.

Škrinjarič, K. (2006). Projekti v šoli - vodstveni izziv. V T. Taštanovska (ur.), Mednarodni projekti $v$ šoli: Priročnik za ravnatelje (str. 6-14). Ljubljana: CMEPIUS, Ministrstvo za šolstvo in šport.

Štrajn, D. (200o). Evalvacija. Ljubljana: Pedagoški inštitut.

Tavčar, M. (2002). Strateški management. Maribor: Ekonomsko-poslovna fakulteta, Inštitut za razvoj managementa.

Tavčar, M., (2009). Management in organizacija. Sinteza konceptov organizacije kot instrumenta in kot skupnost interesov. Koper: Fakulteta za management.

Tekavčič, M. (2002). Merjenje in presojanje uspešnosti poslovanja. V S. Možina (ur.), Management - nova znanja za uspeh (str. 664-693). Radovljica: Didakta.

Trnavčevič, A. (2007). Marketinška kultura v šoli. V A. Trnavčevič (ur.), Ko država šepeta (str. 13-28). Koper: Fakulteta za management.

Vodopivec, V. (2010). Osnove upravljanja in organizacija poslovanja. Ljubljana: Leila. 